\title{
TEKNIK PENGENALAN PEMBULUH DARAH PUNGGUNG TANGAN BERBASIS FITUR LOCAL BINARY PATTERN
}

\author{
${ }^{1}$ Fransisca Joanet Pontoh $*,{ }^{2}$ Henry V.F. Kainde, ${ }^{3}$ Yuri Vanli Akay \\ ${ }^{1,2,3}$ Teknik Informatika, Fakultas Teknik, Universitas Sam Ratulangi \\ ${ }^{1}$ Woloan 2 Tomohon Barat Kota Tomohon Sulawesi Utara Indonesia*fransisca@unsrat.ac.id \\ ${ }^{2}$ Lingkungan IV Taas Tikala Manado Indonesia *valentkainde@unsrat.ac.id ${ }^{3}$ Perkamil, Kelurahan \\ Malendeng Kecamatan Paal Dua Kota ManadoIndonesia*yuriakay@unsrat.ac.id
}

Received: October 19, 2021, Revised: October 22, 2021 Accepted: October 25, 2021

\begin{abstract}
Abstrak
Teknologi biometrik untuk mengidentifikasi dan mengenal karakteristik bagian tubuh manusia yang unik dan tetap sudah banyak dilakukan untuk menjadi bagian dari sistem keamanan di berbagai bidang seperti sidik jari, palm print, wajah, dan iris. Tetapi semua teknik ini masih memiliki keterbatasan. Vena punggung tangan merupakan salah satu bagian dari sistem biometrik populer yang memiliki karakteristik tekstur yang berbeda pada setiap individu yang terletak di dalam tubuh sehingga sulit untuk ditempa ataupun dipalsukan, higienis dan nyaman. Metode yang digunakan adalah experimental atau berbasis pada eksperimen yang bersifat analisis. Tahapan rancangan yang dibangun meliputi input data citra, ekstraksi fitur, pencocokan dan pengenalan citra vena punggung tangan. Data yang digunakan dalam penelitian ini berupa citra punggung tangan tangan kiri dan kanan. Pengambilan gambar dilakukan menggunakan sebuah webcam yang telah dimodifikasi sehingga menangkap citra NIR. Hasil dari penelitian ini menghasilkan metode yang diusulkan dapat melakukan ekstraksi fitur pada citra pembuluh darah punggung tangan dengan akurasi maksimal mencapai $90 \%$ dan waktu komputasi selama 36.0 detik.
\end{abstract}

Kata kunci: Biometrika, Vena Punggung Tangan, Ekstraksi Fitur, Local Binary Pattern

\begin{abstract}
Biometric technology to identify and recognize the unique and permanent characteristics of human body parts has been widely used to become part of security systems in various fields such as fingerprint, palm print, face, and iris. But all of these techniques still have their limitations. Dorsal hand vein is one part of a popular biometric system that has different texture characteristics for each individual located in the body so that it is difficult to forge or forge, hygienic and comfortable. The method used is experimental or based on analytical experiments. The design stages that are built include image data input, feature extraction, matching and recognizing dorsal hand vein images. The data used in this study is an image of the back of the left and right hands. Image capture is done using a webcam that has been modified to capture NIR images. The results of this study resulted in the proposed method being able to perform feature extraction on the back of the hand vein image with a maximum accuracy of $90 \%$ and a computation time of 36.0 seconds.
\end{abstract}

Keywords: Biometric, Dorsal Hand Vein, Feature Extraction, Local Binary Pattern

\section{Pendahuluan}

Teknik biometrik untuk mengidentifikasi dan mengenali fitur unik dan permanen dari bagian tubuh manusia, seperti sidik jari, pengenalan wajah dan iris, memiliki keterbatasan dalam hal kenyamanan dan kinerja[1]. Sistem pengenalan sidik jari mengharuskan pengguna untuk melakukan kontak langsung dengan perangkat sentuh, yang membuatnya kurang higienis dan memungkinkan penyalahgunaan informasi sidik jari pada permukaan sensor. Selain itu, kondisi pada permukaan jari, seperti keringat atau kulit kering, dapat memengaruhi kinerja sistem. Dalam hal sistem pengenalan wajah, kinerja sistem sangat bergantung pada ekspresi wajah dan pencahayaan, yang dapat berubah selama pengambilan gambar. Sistem pengenalan iris mata 
memiliki tingkat akurasi yang cukup tinggi, namun peralatan yang digunakan cukup mahal, dan proses pendataan yang mengharuskan mata berada dekat dengan perangkat sensor dapat mengganggu kenyamanan pengguna. Untuk mengatasi masalah tersebut, diusulkan sistem pengenalan personal berdasarkan susunan pembuluh darah di punggung tangan, yang disebut pengenalan dorsal hand vein.

Pembuluh darah memiliki beberapa keunggulan, yaitu: 1) tidak mudah dipalsukan karena terletak di bawah permukaan kulit[2] ; 2) struktur pembuluh darah tidak berubah seiring bertambahnya usia[2]; 3) proses produksi tidak terpengaruh oleh penyakit kulit seperti kulit dan warna bulu[3] dan 4) tidak mengganggu kenyamanan pengguna selama akuisisi gambar. Sistem pengenalan pembuluh darah tidak memerlukan kontak langsung pengguna dengan sensor, karena cahaya inframerah (near infrared / NIR) digunakan untuk menangkap gambar. Cahaya inframerah diserap oleh pembuluh darah, sehingga bagian pembuluh darah akan lebih gelap dibandingkan bagian jari lainnya. Bagian yang terlihat lebih gelap adalah pola dorsal hand vein.

Di antara berbagai metode ekstraksi fitur tekstur, metode Local Binary Pattern (LBP) adalah yang paling umum digunakan karena dapat mewakili fitur tekstur dan telah diuji dalam banyak penelitian. penelitian biometrik seperti pengenalan wajah [4] dan pengenalan iris [5]. Oleh karena itu, pada penelitian ini diusulkan sistem pengenalan jari vena dengan pendekatan fungsional menggunakan LBP. LBP memiliki variasi tingkat keabuan monoton dan efisiensi komputasi. Identifikasi pembuluh darah punggung tangan pada penelitian ini dilakukan dengan cara pencocokan fitur yang diekstraksi menggunakan Fuzzy k-Nearest Neighbour (Fuzzy kNN). Metode Fuzzy k-NN digunakan karena tidak memerlukan algoritma pembelajaran untuk mengoptimalkan waktu komputasi

Tujuan yang akan dicapai dari penelitian ini adalah untuk melakukan pengenalan dorsal hand vein menggunakan fitur tekstur berbasis Local Binary Pattern. Dan manfaat penelitian ini adalah menghasilkan sebuah sistem pengenalan personal menggunakan pembuluh darah punggung tangan berbasis fitur tekstur Local Binary Pattern yang dapat meningkatkan akurasi pengenalan dan mengoptimalkan waktu komputasi sehingga dapat diaplikasikan untuk sistem pengenalan dorsal hand vein dalam dunia nyata.

\section{Tinjauan Literatur}

Biwasputr Dimas dalam penelitiannya tentang Teknik Pengenalan Ruas Jari Berbasis Fitur LBP dan SVM, menggabungkan Local Binary Model (LBP) sebagai algoritma ekstraksi dan Support Vector Machine (SVM) sebagai metode klasifikasi. Ruasi jari yang diperiksa pada penelitian ini adalah jari telunjuk, jari tengah dan jari manis. Dari pengujian yang dilakukan dengan menggunakan 140 citra latih dan 140 citra uji dari 35 orang diperoleh tingkat presisi menggunakan local binary sample (LBP) reguler dengan parameter $R=\{6,7,12,13\}$ dan $\mathrm{P}=8$ sebagai karakteristik ekstraksi dan One-Againts-All. Support Vector Machine (SVM) dengan kernel linier sebagai classifier, akurasi terbaik adalah $100 \%$ [6]

Rahim, Md Abdur, et al. dengan penelitian berjudul Face recognition using local binary patterns (LBP), mengimplementasikan pengenalan wajah dengan membuat penggunaan ekstraksi fitur dengan Local Binary Pattern. Ini terdiri dari tiga bagian, yaitu wajah representasi, ekstraksi fitur dan klasifikasi. Representasi wajah merepresentasikan bagaimana memodelkan wajah dan menentukan algoritma deteksi yang berurutan dan pengakuan. Fitur yang paling berguna dan unik dari gambar wajah diekstraksi dalam ekstraksi fitur tahap. Dalam klasifikasi tersebut citra wajah dibandingkan dengan gambar dari database. Metode ini mewakili fitur lokal wajah dan mencocokkannya dengan gambar wajah yang paling mirip di database. Itu akurasi sistem dengan Algoritma Local Binary Pattern di atas 100\%[7]

Purwati, Ratih dan Gunawan Ariyanto melakukan penelitian dengan judul Pengenalan Wajah Manusia Berbasis Algoritma Local Binary Pattern. Pada penelitian ini, analisis pengenalan ekspresi wajah manusia dilakukan dengan menggunakan pendekatan fungsional dari algoritma Local Binary Pattern dan mempelajari pengembangan dari algoritma Local Binary Pattern yang paling optimal, dengan menggabungkan Histogram Equalization, Support Vector Machine, dan K-fold cross validation untuk meningkatkan pengenalan citra wajah manusia pada hasil terbaik. Dari hasil kombinasi ketiga metode sebelumnya dan percobaan yang dilakukan, didapatkan hasil yang paling optimal dalam pengenalan wajah manusia menggunakan dataset JAFFE dengan resolusi 92 x 112 piksel dan dengan penggunaan CPU yang tinggi dapat mempengaruhi waktu kecepatan perhitungan selama eksekusi sistem untuk membuat prediksi yang lebih akurat[8]

Retnoningrum, Dwi, Agus Wahyu Widodo, dan Muh Arif Rahman melakukan penelitian dengan judul Ekstraksi Ciri Pada Telapak Tangan Dengan Metode Local Binary Pattern (LBP). Pada penelitian ini, metode yang dapat digunakan dalam proses identifikasi adalah metode ekstraksi ciri Local Binary Pattern (LBP) yang menerapkan jarak kedekatan dan jumlah tetangga yang dibandingkan akan diubah menjadi citra grayscale kemudian dilakukan proses lokalisasi atau proses sharing. gambar di banyak daerah. Kemudian sampai pada 
tahap ekstraksi ciri menggunakan metode LBP. Hasil paling akurat yang diperoleh dari penelitian ini adalah 92,31 dengan jarak mendekati 2 , jumlah tetangga yang dibandingkan $=8$, jumlah daerah adalah 16 , dan pembagian tinggi $=4$ dan lebar $=4[9]$

Al Rivan, Muhammad Ezar dan Siska Devella melakukan penelitian dengan judul Pengenalan Iris Menggunakan Fitur Local Binary Pattern dan RBF Classifier. Pada penelitian ini citra iris mata akan dilakukan pre-processing dengan menghilangkan noise seperti rambut dan kelopak mata kemudian sebagai hasil ekstraksi fitur dari citra iris yang telah diproses sebelumnya menggunakan algoritma Local Binary Pattern (LBP). Setelah ekstraksi fitur selesai, proses selanjutnya adalah validasi menggunakan Radial Basis Function (RBF). Setelah validasi, model RBF diuji dengan data iris yang berbeda. Akurasi maksimum yang diperoleh dengan menggunakan fungsi LBP dan RBF adalah 83,33\%[10]

\section{Metode Penelitian}

a. Instrumen Penelitian

Instrumen penelitian yang akan digunakan dalam tahap implementasi penelitian ini terdiri atas 2 bagian yaitu :

- Perangkat Lunak (Software)

Perangkat lunak yang penulis gunakan dalam melakukan penelitian adalah sebagai berikut :

- $\quad$ Sistem operasi Windows 10

- $\quad$ Aplikasi code editor Matlab R2017a untuk menulis kode program.

- Microsoft Office Word 2010 untuk pembuatan laporan dan dokumentasi hasil penelitian.

- Perangkat Keras (Hardware)

Perangkat keras yang penulis gunakan dalam melakukan penelitian adalah sebagai berikut:

- $\quad$ Prosesor AMD A6-9220 RADEON r4, 5 compute cores 2C+3G 2.50GHz

- $\quad$ RAM ukuran 4.00 GB

- Layar monitor ukuran 14"

- Webcam NIR

b. Rancangan Sistem

Sistem yang akan dibangun meliputi input data citra, ekstraksi fitur, pencocokan dan pengenalan citra dorsal vein berdasarkan fitur hasil ekstraksi. Gambar di bawah menjelaskan flowchart sistem yang akan dibangun

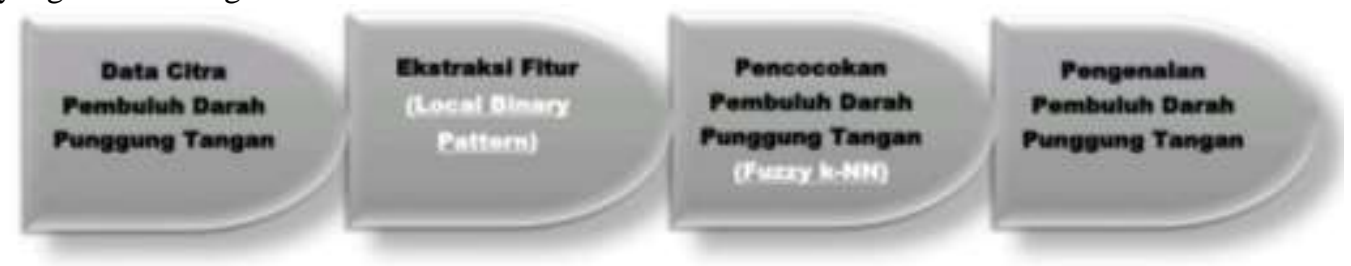

Gambar 1. Flowchart sistem pengenalan pembuluh punggung tangan

c. Eksperimen

- Data Citra

Pada penelitian ini digunakan citra punggung tangan kiri dan kanan lakilaki dan perempuan $\geq 17$ tahun . Pengambilan gambar menggunakan sebuah kamera webcam (MTech Webcam) yang telah dimodifikasi sehingga bisa menangkap citra NIR. Pengambilan citra pembuluh darah punggung tangan dilakukan sebanyak 6 kali untuk orang yang sama. Karena tidak memiliki batasan posisi, postur dan pencahayaan, maka bentuk punggung tangan memiliki variasi ukuran dan rotasi berbeda dan warnanya berbeda pula.

- Tahap Ekstraksi Fitur Menggunakan Metode LBP 
Sebelum dilakukan ekstraksi fitur, area punggung tangan dilakukan deteksi ROI kemudian pre-processing yaitu mengubah citra menjadi citra grayscale. Setelah itu semua citra dilakukan ekstraksi fitur LBP

- Tahap Pencocokan menggunakan F k-NN

Pengenalan Dorsal hand vein dilakukan dengan mencocokkan fitur tekstur pembuluh darah punggung tangan pada citra uji dan fitur tekstur pembuluh darah punggung tangan pada citra latih menggunakan metode Fuzzy k-NN. Untuk mengevaluasi sistem pengenalan pembuluh darah punggung tangan pada sistem yang dibangun digunakan pengujian one-to-many. Untuk menunjang proses pengenalan dilakukan pembatasan nilai ambang, nilai ambang digunakan untuk membedakan pemilik citra dari tiap individu. Nilai ambang ditentukan dengan cara menghitung nilai keanggotaan pada fuzzy k-NN, dimana citra yang dibaca benar akan diambil nilai bobotnya yang selanjutnya total citra yang dibaca benar akan dibagi dengan total keseluruhan citra latih untuk mendapatkan nilai ambang terbaik dalam membedakan citra uji yang ada dalam database dan citra uji yang tidak ada dalam database kemudian akan dihitung besar akurasi dari pengenalan seluruh citra testing. Akurasi diperoleh dengan menghitung jumlah dari pengenalan citra data testing yang benar.

\section{$4 \quad$ Hasil dan Pembahasan}

a. Data Uji Coba

Data yang digunakan pada penelitian ini berjumlah 140 citra punggung tangan yang diambil langsung menggunakan webcam yang dimodifikasi menjadi webcam infrared yang berformat JPEG. Komposisi dalam dataset ini terdiri dari 4 sampel untuk setiap orang.

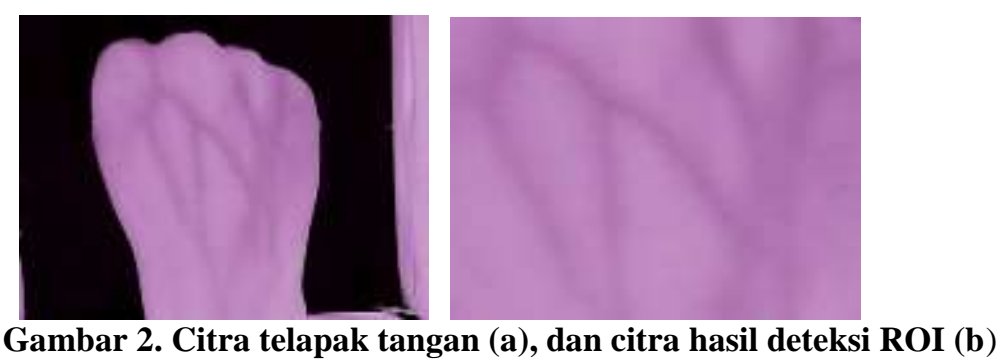

Dalam uji coba yang dilakukan, dataset dibagi menjadi dua bagian, yaitu 105 citra (3 sampel untuk setiap orang) untuk database dan 35 citra (1 sampel untuk setiap orang) untuk data testing. Dalam sistem yang dibangun, seluruh data uji coba (baik citra uji maupun citra database) akan melalui tahap deteksi Region of Interest (ROI) dan praproses sebelum melalui tahap ekstraksi fitur.

Citra telapak tangan pada Gambar 3 (a) merupakan contoh data uji coba yang digunakan dalam penelitian ini. Setelah melalui tahap deteksi ROI diperoleh citra ROI dari citra telapak tangan, seperti yang ditunjukkan Gambar 3(b). Selanjutnya beberapa tahapan praproses akan dilakukan terhadap citra ROI.

ROI extracted image merupakan citra ROI yang akan dipraproses. Tahap awal dari praproses adalah resize ukuran citra menjadi 128 x 128 piksel menggunakan interpolasi bikubik. Proses enhancement terhadap citra dilakukan menggunakan contrast-limited adaptive histogram equalization (CLAHE).

b. Uji Coba

Pada tahap uji coba, sistem pengenalan dorsal vein yang dibangun akan diuji dengan menggunakan pengujian identifikasi yaitu pengujian one-to-many, setiap citra uji dicocokkan dengan seluruh citra database kemudian akan dihitung besar akurasi dari pengenalan seluruh citra uji. Dalam pengujian identifikasi, sistem dievaluasi dengan menggunakan CRR (Correct Recognition Rate). 
https://jurnal.amikwidyaloka.ac.id/index.php/awl

jurnal@amikwidyaloka.ac.id / editor.jurnalwidya@gmail.com

Proses pengujian dilakukan pada 140 citra dorsal vein, dengan cara mencocokkan 35 citra uji dengan 105 citra database. Pencocokan citra uji dan citra dalam database dilakukan dengan menggunakan metode Fuzzy k-NN. Akurasi pengenalan CRR diperoleh dengan menghitung perbandingan jumlah dari pengenalan citra data uji yang benar dengan jumlah keseluruhan data uji. Hasil akurasi yang diperoleh akan divalidasi menggunakan prosedur k-fold cross validation dengan $\mathrm{k}=4$, karena terdapat 4 jumlah citra sampel untuk setiap telapak tangan. Dari prosedur $k$ fold cross validation yang digunakan, diperoleh rata-rata akurasi (mean accuracy) untuk setiap hasil uji coba.

Pada tahapan uji coba juga dilakukan pengukuran waktu komputasi untuk mengukur kinerja dari sistem yang telah dibangun. Waktu komputasi yang diperoleh pada uji coba ini merupakan total waktu komputasi untuk pengenalan keseluruhan citra (35 citra uji).

1) Hasil Uji Coba Parameter k pada Fuzzy k-NN

Setiap citra akan mengalami proses ekstraksi fitur dengan menggunakan metode LBP dengan 4 nilai $\mathrm{N}$ yang berbeda $(\mathrm{N}=7,9,11$ dan 13). Tujuan dari uji coba ini adalah untuk mendapatkan parameter $\mathrm{N}$ yang optimal untuk pengenalan dorsal vein. Fitur tekstur dari citra uji yang dihasilkan pada uji coba ini akan dicocokkan dengan fitur tekstur pada database menggunakan Fuzzy k- NN dengan $k=2$. Akurasi pengenalan CRR diperoleh dengan menghitung perbandingan jumlah dari pengenalan citra data uji yang benar dengan jumlah keseluruhan data uji. Hasil akurasi tersebut selanjutnya divalidasi menggunakan 4-fold cross validation, sehingga untuk setiap $\mathrm{N}$ jumlah piksel ketetanggaan, diperoleh rata-rata akurasi (mean accuracy). Selain akurasi, pada uji coba ini juga dilakukan evaluasi dan analisis terhadap waktu komputasi untuk setiap $\mathrm{N}$ jumlah piksel ketetanggaan. Waktu komputasi yang diperoleh pada uji coba ini merupakan total waktu komputasi untuk pengenalan keseluruhan citra (35 citra uji).

2) Hasil Uji Coba LBP

Visualisasi fitur tekstur hasil ekstraksi dengan menggunakan metode LBP ditunjukkan pada Gambar 3.

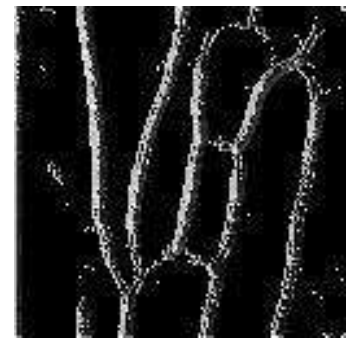

Gambar 3. Contoh visualisasi ekstraksi fitur menggunakan LBP

Akurasi pengenalan CRR diperoleh dengan menghitung perbandingan jumlah dari pengenalan citra data uji yang benar dengan jumlah keseluruhan data uji. Hasil akurasi tersebut divalidasi menggunakan 4-fold cross validation, sehingga diperoleh rata-rata akurasi dari metode LBP

Tabel 1. Hasil Uji Coba Metode LBP

\begin{tabular}{|c|c|c|c|c|}
\hline K-Fold & 1 & 2 & 3 & 4 \\
\hline Akurasi Pengenalan (\%) & 80 & 80 & 86 & 90 \\
\hline
\end{tabular}

3) Kesalahan Pengenalan Dorsal Vein

Dalam uji coba yang dilakukan, terdapat kesalahan dalam pengenalan dorsal hand vein yang disebabkan oleh kesalahan pada tahap deteksi ROI dan adanya pseudo fitur yang dihasilkan pada tahap ekstraksi fitur. Kesalahan deteksi ROI disebabkan oleh variasi translasi dan rotasi pada dataset citra telapak tangan. Adapun pseudo fitur atau fitur palsu merupakan tepi citra ROI yang dianggap sebagai fitur vein setelah hasil ekstraksi fitur.

- Kesalahan pada tahap deteksi ROI 
Proses penetapan ROI mememilik pengaruh yang signifikan pada keakuratan pengenalan Dalam sistem ini, deteksi ROI dilakukan secara manual, tidak berada pada posisi yang sama dan dapat dipastikan bahwa akan berada pada posisi yang berbeda untuk setiap punggung tangan. Karena ekstraksi ROI yang tidak stabil ini, maka terjadi beberapa kesalahan dalam pengenalan.

- Pseudo fitur

Sama seperti penelitian vein recognition yang terdahulu (Lee, 2012; Kang, 2014), fitur tekstur vein pada penelitian ini juga dipengaruhi oleh batas tepi ROI yang membentuk pseudo fitur (tepi citra yang dianggap sebagai vein) dari citra dorsal hand vein yang dapat mempengaruhi akurasi pengenalan.

\section{$5 \quad$ Kesimpulan}

Berdasarkan penelitian yang sudah dilakukan, dapat disimpulkan bahwa pengenalan personal dengan melalui teknik pengenalan pembuluh darah punggung tangan menggunakan ekstraksi fitur Local Binary Pattern dapat bekerja dengan baik. Metode ini melakukan ekstraksi fitur pada citra pembuluh darah punggung tangan dengan akurasi maksimal mencapai 90\% dan waktu komputasi selama 36.0 detik. Hal ini karena metode tersebut dapat menghasilkan deskriptor citra yang berukuran kecil dan sifatnya yang invarian karena hampir tidak terpengaruh oleh pencahayaan yang berbeda

\section{Referensi (Reference)}

[1] Watanabe, Masaki, et al. "Palm vein authentication technology and its applications." Proceedings of the biometric consortium conference. 2005.

[2] Doublet, Julien, Olivier Lepetit, and Marinette Revenu. "Contact less palmprint authentication using circular Gabor filter and approximated string matching." Signal and Image Processing (SIP 2007). 2007.

[3] Lee, Jen-Chun. "A novel biometric system based on palm vein image." Pattern Recognition Letters 33.12 (2012): 1520-1528.

[4] Mujib, Khusnil, Achmad Hidayatno, and Teguh Prakoso. "Pengenalan Wajah Menggunakan Local Binary Pattern (Lbp) Dan Support Vector Machine (Svm)." Transient: Jurnal Ilmiah Teknik Elektro 7.1 (2018): 123-130.

[5] He, Yuqing, et al. "Iris feature extraction method based on LBP and chunked encoding." 2011 Seventh International Conference on Natural Computation. Vol. 3. IEEE, 2011.

[6] Biwasputr Dimas. Teknik Pengenalan Ruas Jari Berbasisi Fitur LBP dan SVM. Universitas Telkom. Bandung. 2013.

[7] Rahim, Md Abdur, et al. "Face recognition using local binary patterns (LBP)." Global Journal of Computer Science and Technology (2013).

[8] Purwati, Ratih, and Gunawan Ariyanto. "Pengenalan Wajah Manusia Berbasis Algoritma Local Binary Pattern." Emitor: Jurnal Teknik Elektro 17.2 (2017): 70-79.

[9] Retnoningrum, Dwi, Agus Wahyu Widodo, and Muh Arif Rahman. "Ekstraksi Ciri Pada Telapak Tangan Dengan Metode Local Binary Pattern (LBP)." Jurnal Pengembangan Teknologi Informasi dan Ilmu Komputer e-ISSN 2548 (2019): 964X.

[10] Al Rivan, Muhammad Ezar, and Siska Devella. "Pengenalan Iris Menggunakan Fitur Local Binary Pattern dan RBF Classifier." Simetris: Jurnal Teknik Mesin, Elektro dan Ilmu Komputer 11.1 (2020): 97 106. 